\title{
Działania klubów piłkarskich na rzecz ochrony środowiska - studium przypadku Forest Green Rovers
}

\author{
Adrian Pietrzyk \\ Uniwersytet Ekonomiczny w Katowicach, Wydział Zarządzania, adrian.pietrzyk@edu.uekat.pl, \\ ORCID: 0000-0002-4724-1659
}

Streszczenie: Artykuł skupia się na istocie działań prospołecznych w obszarze troski o środowisko. W pierwszej części przedstawiono istotę oraz zarys działań CSR. W części metodycznej dokonano rozpoznania za pomocą studium przypadku. Podmiotem badań był angielski klub Forest Green Rovers F.C., który uchodzi za najbardziej ekologiczny klub piłkarski na świecie. Głównym celem artykułu było pokazanie działań, jakie podejmuje klub Forest Green Rovers na rzecz środowiska naturalnego. Eksploracyjnym celem poznawczym opracowania stało się wskazanie różnic pomiędzy klubami w Polsce a angielskim klubem Forest Green Rovers, natomiast celem utylitarnym - zwiększenie świadomości o roli społecznej klubu piłkarskiego. Przedstawione zostały zarówno jego obecne działania na rzecz wzrostu zainteresowania tematami z obszaru ekologii, jak i plany na przyszłość. W ostatniej części artykułu znalazły się również implikacje zarządcze dla polskich klubów piłkarskich.

Słowa kluczowe: CSR, ochrona środowiska, ekologia w piłce nożnej.

Kod JEL: Z20.

\section{Wstęp}

Artykuł porusza kwestię wykorzystania działań proekologicznych podczas promocji klubu sportowego na przykładzie Forest Green Rovers F.C. (FGR) angielskiego klubu piłkarskiego. Dotyczy on tematu szeroko rozumianego sukcesu przedsiębiorstwa sportowego nie tylko na płaszczyznach sportowej (wygrywanie spotkań, zdobywania mistrzostw, trofeów) czy finansowej (przychody z transfe- 
rów, sponsorów), ale również w obszarze działań ekologicznych, które z założenia prowadzą do sukcesów społecznych. Piłka nożna jest prawdopodobnie najpopularniejszym sportem na świecie. Według klasyfikacji znajdującej się na portalu WorldAtlas (ranking opracowany w październiku 2020 r.) piłka nożna to sport, którym interesuje się około 4 mld osób na świecie (WorldAtlas, 2020); wyprzedza takie dyscypliny jak: krykiet (2,5 mld fanów), hokej (2 mld fanów), tenis (1 mld fanów) czy siatkówka (900 mln fanów). Potwierdza to również ranking zamieszczony na portalu SportsShow.net. W badaniach przyjęto kryteria, takie jak: oglądalność $\mathrm{w}$ telewizji, popularność $\mathrm{w}$ internecie, wartość umów sponsorskich oraz telewizyjnych, liczba lig zawodowych, liczba krajów, w których sport jest popularny, średnia pensja, liczba lig. Również według rankingu Sportshow.pl, który ukazał się 23 marca 2021 r., najpopularniejszy sport to piłka nożna. Według szacunków interesuje się nią około 3,5 mld ludzi na całym świecie. Drugi w zestawieniu jest krykiet (2,5 mld), a następnie koszykówka (2,2 mld) oraz hokej (2 mld). Na piątym miejscu znalazł się tenis, którego szacunkowa liczba fanów wynosi ok. 1 mld na całym świecie (SportsShow, 2021). Bez wątpienia piłka nożna jest sportem o zasięgu globalnym. Na przykład angielska drużyna Manchester United posiada kluby kibica na całym świecie - według danych z dnia 24 marca 2021 r. było ich 262 (Manchester United, 2020). Podobnie sytuacja wygląda $\mathrm{z}$ innymi klubami, których kibiców można spotkać w różnych krajach świata. Ponad 300 fanklubów na całym świecie ma Liverpool FC (Liverpool FC, n.d.).

O tym, że futbol jest sportem globalnym świadczą również miejsca piłkarskich imprez międzynarodowych. Mistrzostwa świata w 2022 r. mają odbyć się w Katarze, a następne - w USA, Meksyku i Kanadzie. Poprzednie w latach 2018, 2014, 2010, 2006, 2002, 1998, 1994 rozegrano kolejno w: Rosji, Brazylii, RPA, Niemczech, Korei Południowej i Japonii, Francji oraz w Stanach Zjednoczonych. Ostatnie mistrzostwa świata w Rosji według FIFA oglądało aż 3,5 mld ludzi. To ponad połowa populacji świata w wieku od 4 lat wzwyż (Kubiak, 2018). Zostając przy wskaźniku, jakim jest oglądalność, mecz Polska-Portugalia w 2016 r. zobaczyło prawie $16 \mathrm{mln}$ widzów, co dało $86,57 \%$ udziału w rynku. Tylko pogrzeb papieża Jana Pawła II oglądało więcej osób - szacuje się, że ponad $21 \mathrm{mln}$ widzów (Onet, 2016). Oprócz przytoczonych wcześniej rankingów, liczby fanklubów czy liczby oglądalności o sporej popularności futbolu świadczą również gaże zawodników. Najlepiej zarabiający piłkarze w sezonie 2020/2021 to: Lionel Messi - 92,7 mln GBP oraz Cristiano Ronaldo - 90,3 mln GBP (Forbes, 2018). 
Na komercjalizację futbolu wskazują przychody klubów piłkarskich. Według ostatniego raportu Deloitte Football Money League 2020 (Deloitte, 2020) lider rankingu - FC Barcelona - osiągnęła przychód za 2019 r. wynoszący 840,8 mln EUR, czyli około prawie 4 mld PLN. W Polsce pomimo zdecydowanie niższych przychodów, piłka nożna to coś więcej niż sport dla wielu kibiców, coś więcej niż biznes dla wielu przedsiębiorców-sponsorów. Mimo że w internecie można odnaleźć artykuły sugerujące, że najpopularniejszym sportem na świecie jest koszykówka czy krykiet, to bez wątpienia można stwierdzić, że w Polsce jest to piłka nożna; nie ma źródeł, które wskazywałby, że może być inaczej. Osoby trenujące piłkę nożną stanowią prawie $40 \%$ wszystkich ćwiczących w klubach sportowych (Bankier, 2019). W Polsce działa kilka tysięcy klubów piłkarskich najwięcej w Małopolsce (616) i na Dolnym Śląsku (590) (Meczyki, 2019). Dlaczego jednak jest to istotne z perspektywy niniejszego artykułu? Kluby międzynarodowe mają globalny zasięg i stanowią globalny środek przekazu informacji dzięki swoim działaniom, dobrym praktykom czy reklamom. Kluby w Polsce nie są markami globalnymi, jednak mają olbrzymi wpływ na kształtowanie lokalnej społeczności. Dlatego też rola klubów w edukacji proekologicznej społeczeństwa powinna stać się częścią ich strategii CSR. Ekwiwalent reklamowy, jaki generują kluby za sprawą swojej medialności, może przyczynić się do propagowania pozytywnych działań na rzecz środowiska.

Artykuł został podzielony na trzy części. W pierwszej części można znaleźć wyjaśnienie pojęcia społecznej odpowiedzialności biznesu - CSR (Corporate Social Responsibility), w tym jej komponentów, a także opis klubu Forest Green Rovers. Druga cześć omawia działania proekologiczne w społeczeństwie i szerzenie dobrych praktyk $\mathrm{w}$ trosce o środowisko. W ostatniej części artykułu zamieszczono dyskusję oraz rekomendacje zarządcze dla klubów piłkarskich w Polsce, które rzadko wprowadzają do swojej komunikacji akcje związane bezpośrednio z troską o środowisko naturalne. Główny cel opracowania to pokazanie działań klubu Green Forest Rover na rzecz środowiska naturalnego. Eksploracyjnym celem poznawczym stało się wskazanie różnic pomiędzy klubami w Polsce a angielskim klubem FGR, natomiast celem utylitarnym - zwiększenie świadomości o roli społecznej, jaką klub piłkarski powinien realizować.

\section{Przegląd literatury}

W przeciwieństwie do tematów takich jak sponsoring, marketing, zarządzanie w sporcie, w bazach naukowych (m.in. https://www.researchgate.net, https:// www.scopus.com, yadda.icm.edu.pl) widoczny jest deficyt publikacji na temat 
społecznej odpowiedzialności klubów piłkarskich na rzecz środowiska naturalnego. Nie ma jednoznacznej definicji społecznej odpowiedzialności biznesu. CSR podkreśla szerokie formułowanie celów danego przedsiębiorstwa, nie tylko przez pryzmat zysków/zwiększania wartości firmy, ale również biorąc pod uwagę aspekty społeczne (Zuzek, 2012, s. 198). Mimo że obecnie działania CSR są dość popularne i szeroko omawiane w literaturze, to nie jest to pojęcie nowe. Wykształciło się na fundamencie etyki biznesu (Kubiczek, 2020), a można było zetknąć się z nim już na przełomie XIX i XX w. (Bernatt, 2009, s. 5). CSR w sektorze komercyjnym ma wpływ również na wyniki finansowe przedsiębiorstwa. Działania społeczne według wielu autorów prowadzą nie tylko do poniesienia dodatkowych kosztów oraz spełnienia dobrych uczynków, ale również do uzyskania przewagi konkurencyjnej (Kubiczek, 2019; Kuraszko \& Rok, 2007).

Mimo różnych interpretacji pojęcia CSR, zależnych od rodzaju przedsiębiorstwa, jego zasobów, celów oraz balansu pomiędzy bezinteresowną pomocą a chęcią osiągnięcia zysku, CSR został zdefiniowany w normie ISO 26000 (Kantor \& Kubiczek, 2021; Sznajder, 2013, s. 195). Norma określa zakres oraz kluczowe obszary społecznej odpowiedzialności biznesu. Są to: ład organizacyjny, prawa człowieka, praktyki z zakresu pracy, uczciwe praktyki operacyjne, zagadnienia konsumenckie, zaangażowanie społeczne i rozwój społeczności lokalnej oraz środowisko. Można jednak zauważyć, że obszary te w działaniach praktycznych się przenikają, co oznacza, że przedsiębiorstwo może wykonać działanie, które będą cechowały np. troska o środowisko i zaangażowanie lokalnej społeczności. Powyższa norma według Polskiego Komitetu Normalizacyjnego powinna mieć wpływ na: przewagę konkurencyjną, reputację organizacji, zdolność pozyskiwania i zatrzymywania pracowników, konsumentów, klientów, użytkowników, morale, zaangażowanie i wydajność pracowników, opinie inwestorów, właścicieli, darczyńców, sponsorów i społeczności finansowej oraz relacje organizacji z przedsiębiorstwami, instytucjami rządowymi, mediami, dostawcami, podobnymi organizacjami, klientami oraz społecznością, w obrębie której organizacja funkcjonuje (PKN, 2013). Mimo że norma kierowana jest do różnych przedsiębiorstw na całym świecie, to wszystkie jej komponenty idealnie opisują każdy obszar działania klubów piłkarskich, które są specyficznymi przedsiębiorstwami ze względu na czynniki takie jak: silna lojalność odbiorców (kibiców) wobec marki, wpływ na kształtowanie młodzieży, zwiększanie przywiązania do klubu w czasie socjalizacji czy specyficzny proces segmentacji klientów. 
Sukces klubu piłkarskiego można (w zależności od jego specyfiki) rozpatrywać na wielu płaszczyznach: sportowej, społecznej, finansowej i marketingowej. Aby jednak go osiągnąć, kluby powinny działać jak inne przedsiębiorstwa, zgodnie z regułami biznesowymi. Dlatego też wiele $\mathrm{z}$ nich $\mathrm{w}$ Polsce angażuje się w projekty CSR oraz realizuje coroczne raporty z projektów o charakterze prospołecznym (Skałecka, 2017, s. 21). Kluby z roku na rok coraz bardziej angażują się w pomoc lokalnej społeczności, aby promować m.in. marketing przez CSR (reklamować np. sponsorów klubów podczas akcji społecznych). Niestety, nadal brakuje zaangażowania klubów w Polsce w segment działań ekologicznych. Pokazują to badania przygotowane przez Sport Impact (Zembura et al., 2020). W raporcie na wynik klubu składały się trzy obszary: społeczeństwo, środowisko i rządzenie, które zostały opisane jako przejawy odpowiedzialności społecznej. Zbadane zostały kluby Fortuny 1 Ligi (druga klasa rozgrywek piłkarskich w Polsce) w sezonie 2019/2020. Każdy z 18 klubów otrzymał punkty za działania na rzecz społeczeństwa oraz w obszarze rządzenia. Tylko trzy kluby - Miedź Legnica, GKS Bełchatów i Stomil Olsztyn - zaangażowały się w działania dotyczące ochrony środowiska. Wiele z nich odnosiło się do obszaru stadionu i infrastruktury. Żaden z klubów nie poinformował o wykorzystaniu np. odnawialnych źródeł energii czy zużycia wody. Kluby nie prowadziły również działań edukacyjnych, których celem byłoby uświadamianie społeczeństwa (kibiców, adeptów akademii, sponsorów), jak dbać o środowisko. Jedynie 22\% klubów Fortuny 1 Ligi według powyższego raportu przedstawiło na stronie wskazówki, jak dotrzeć na stadion za pomocą innych środków transportu niż samochód. Ani jeden klub nie dodał również informacji dotyczącej segregacji odpadów, korzystania z ekologicznych rozwiązań w oparciu o ideę zrównoważonego rozwoju (Zembura et al., 2020).

Czy piłka nożna może jednak iść w parze z działaniami proekologicznymi? Jest to możliwe oraz niesie za sobą wiele korzyści, jak wskazują przykłady wielu klubów. Jednym z nich jest rozpoznawalny przez kibiców na całym świecie Forest Green Rovers F.C. „Zielone diabły” cieszą się olbrzymią popularnością; często można przeczytać o nich również w polskich mediach (na wielu portalach branżowych, np. Interia, TVP Sport). Medialność klubu nie powinna dziwić, ponieważ angielski futbol jest jednym z najpopularniejszych na całym świecie. Jednak w tym przypadku nie chodzi o sukcesy sportowe. Obecnie klub rozgrywa swoje mecze w League Two (czwarty poziom rozgrywek w Anglii) (Flash Score.com, n.d.), a mimo to cieszy się popularnością. W swojej długiej historii (data złożenia to 1889 r.) klub nigdy nie osiągnął sukcesów sportowych na are- 
nie krajowej, a tym bardziej na arenie międzynarodowej. Ich największym sukcesem było zdobycie 5. miejsca w League Two w sezonie 2018/2019. W sezonach 2008/2009 oraz 2009/2010 udało im się dostać do trzeciej rundy Pucharu Anglii. Nigdy nie zakwalifikowali się do znaczących rozgrywek międzynarodowych, które są głównym źródłem rozpoznawalności, czyli do Ligi Mistrzów czy Ligi Europy UEFA. Mimo to klub jest rozpoznawalny poza swoim regionem. Pojawia się pytanie: co jest źródłem popularności tego klubu, którego siedziba znajduje się w ok. 5. tysięcznej angielskiej miejscowości - Nailsworth? Źródłem popularności nie są ich wyniki sportowe, tylko osiąganie sukcesów na płaszczyźnie społecznej i marketingowej.

\section{Metodyka}

W pracy jako metodę badawczą wykorzystano studium przypadku oraz dokonano systematycznego przeglądu literatury. Wybór metody badawczej wiąże się z jej założeniem, podkreślanym przez R. Stake'a, które brzmi następująco: „studium przypadku jest podejściem skierowanym na odkrycie wyjątkowości i niepowtarzalności (particularity) oraz złożoności (complexity) pojedynczego przypadku" (Mizerek, 2017, s. 11, za: Stake, 1997, s. 127). Każdy przypadek, również ten, który badany jest w niniejszym artykule, posiada własną niepowtarzalną charakterystykę. Studium przypadku jest wykorzystywane jako metoda naukowa w wielu dziedzinach nauki - jest to wszechstronny opis danego zjawiska. Dokonano również systematycznego przeglądu literatury przedmiotu z zakresu społecznej odpowiedzialności biznesu. Narzędzie to pozwala na identyfikację luki badawczej oraz najbardziej pożądane kierunki dalszych badań i sposób analizy danych surowych. Wybór na uzupełnienie studium przypadku tą metodą spowodowany jest jej walorami, m.in. ochroną procesu doboru publikacji (Czakon et al., 2019). Podejście systematyczne zostało przeprowadzone na wszystkich etapach: wyszukiwania, selekcji, syntezy i analizy (Orłowska et al., 2017). Przegląd traktowany jest jako synteza wcześniej opublikowanej wiedzy na temat społecznej odpowiedzialności biznesu. Został on przeprowadzony w sposób obiektywny, rzetelny i podsumowuje określony obszar teoretyczny (Klimas, 2011). Przeglądu dokonano w okresie 11.2020-02.2021. Metoda posłużyła do zgromadzenia materiału empirycznego. Społeczna odpowiedzialność biznesu (CSR) to pojęcie, które występuje powszechnie zarówno w literaturze, jak i praktyce, dlatego też wiele wykorzystanych źródeł to strony internetowe oraz literatura popularnonaukowa, gdyż podane zostały w nich praktyczne możliwości wykorzystania działań prospołecznych do realizacji strategii klubów. 


\section{Wyniki badań}

Forest Green Rovers to klub uznany przez FIFA za najbardziej ekologiczny klub piłkarski na świecie. Stał się również pierwszym wegańskim klubem piłkarskim (Samuel, 2018, s. 1159-1160). Już na początku wieku miał on być podmiotem służącym lokalnej społeczności oraz wspierającym osoby, które były zagrożone społecznym wykluczeniem - młodzież, osoby starsze (Beardmore et al., 2020, s. 2,8). Za pomocą środków przekazu, takich jak strona internetowa czy portale społeczne, zaznacza, że stanowi pierwszy klub na świecie, który jest w pełni odpowiedzialny społecznie. Stanowi to niewątpliwy precedens w piłkarskim środowisku, nastawionym na zwiększanie zysków i wygrywanie meczów. Cały system zarządzania środowiskowego został zaprojektowany w celu spełnienia wymogów Systemu Ekozarządzania i Audytu (Eco-Management and Audit Scheme - EMAS) (Ceglińska, 2015). Warto zaznaczyć, że jest to unijny system certyfikacji środowiskowej, adresowany do różnych podmiotów. System, podobnie jak norma ISO14001, jest dobrowolny. Certyfikat przyznaje się przedsiębiorstwom, które wdrożą system w oparciu o treści zawarte w polityce środowiskowej (Generalna Dyrekcja Ochrony Środowiska, n.d., 2020).

Oprócz certyfikacji EMAS oraz wyróżnienia przez Międzynarodową Federację Piłki Nożnej, klub otrzymał również wyróżnienie od Organizacji Narodów Zjednoczonych. FGR został pierwszą organizacją sportową, której neutralność węglowa została uznana przez ONZ (Dziennik Trybuna, n.d.). Całość działań silnie nastawionych na rozwój ekologiczny rozpoczęła się dzięki właścicielowi i prezesowi klubu, którym od 2010 r. (Climate Action, 2017) jest Dale Vince, będący jednocześnie prezesem firmy Ecotricity. Firma ta ma 60 turbin wiatrowych w całym kraju i ponad 125 tys. klientów. Sam właściciel jest weganinem i propagatorem zrównoważonego rozwoju opartego na szacunku do środowiska naturalnego (PolskieRadio24.pl, 2016). Vince podczas wywiadu dla dziennika „The Guardian” powiedział, że inwestycja w klub była „okazją do zamanifestowania przekazu do wiadomości publicznej” (James, 2017). Zaznaczył, że w świecie futbolu nie mówi się o środowisku i za pomocą kanałów komunikacji, jakie posiada klub (media społecznościowe, reklamy, bilbordy, bandy LED itp.), chciał przekazać informację o zrównoważonym rozwoju (James, 2017). Klub dla założyciela Ecotricity jest pewnego rodzaju osobistym manifestem. On sam nie stroni od wywiadów, w których chętnie omawia swoje życiowe założenia, tj. nacisk na wykorzystanie odnawialnych źródeł energii, wymuszenie zmiany zachowań w społeczeństwie pod kątem troski o środowisko, zaprzestanie konsumpcji mię- 
sa czy oddanie ziemi uprawnej naturze, aby ograniczyć emisję $\mathrm{CO}_{2}$. Jednocześnie zaznacza on, że był to proces ewolucji, który trwa do dziś. Zmiana nie nastąiła jednego dnia, tylko była wprowadzana stopniowo. Działania klubu na rzecz ochrony środowiska zostały przedstawione w tabeli 1.

Tabela 1. Działania na rzecz środowiska lokalnego klubu FGR

\begin{tabular}{|c|c|}
\hline Plan budowy nowego stadionu & $\begin{array}{l}\text { Klub jest na etapie starań o nowy stadion, który ma } \\
\text { zostać uznany za najbardziej ekologiczny na świecie. } \\
\text { Ma on być } 1 \text {-poziomowy i w większości wykonany } \\
\text { z drewna, całkowicie zasilany odnawialnymi źródłami } \\
\text { energii oraz otoczony drzewami, a jego pojemność ma } \\
\text { być optymalna oraz dostosowana do potrzeb kibiców } \\
\text { i wynosić } 5000 \text { miejsc }\end{array}$ \\
\hline Modernizacja obecnego stadionu & $\begin{array}{l}\text { Na dachu stadionu zamontowane zostały panele } \\
\text { fotowoltaiczne }\end{array}$ \\
\hline Wegańskie potrawy na stadionie & $\begin{array}{l}\text { W klubowej restauracji nie można kupić produktów } \\
\text { mięsnych oraz innych produktów pochodzenia } \\
\text { zwierzęcego }\end{array}$ \\
\hline Ekologiczna murawa & $\begin{array}{l}\text { Murawa jest pielęgnowana bez użycia chemikaliów } \\
\text { i użyźniana naturalnym nawozem }\end{array}$ \\
\hline Automatyczny system dbania o murawę & $\begin{array}{l}\text { Automatyczne kosiarki, które ładowane są za pomocą } \\
\text { energii słonecznej dbają o długość trawy na murawie } \\
\text { stadionu }\end{array}$ \\
\hline Zbiórki wody & $\begin{array}{l}\text { Klub do pielęgnowania murawy używa wody, którą } \\
\text { zbiera w okolicach stadionu }\end{array}$ \\
\hline Porty ładowania samochodów elektrycznych & $\begin{array}{l}\text { Na stadionie znajdują się miejsca, gdzie można } \\
\text { naładować samochody elektryczne }\end{array}$ \\
\hline Tablice informacyjne na stadionie & $\begin{array}{l}\text { Na gości, którzy zwiedzają stadion, czekają tablice } \\
\text { informacyjne podkreślające znaczenie zrównoważo- } \\
\text { nego rozwoju w codziennym życiu }\end{array}$ \\
\hline Ekologiczne piwo & $\begin{array}{l}\text { Na stadionie można zakupić również ekologiczne } \\
\text { piwo }\end{array}$ \\
\hline Biodegradowalne pojemniki & $\begin{array}{l}\text { Napoje ciepłe sprzedawane są w biodegradowalnych } \\
\text { pojemnikach }\end{array}$ \\
\hline Zakaz jedzenia mięsa przez wszystkich pracowników & $\begin{array}{l}\text { Pracownicy (w tym piłkarze) mają zakaz jedzenia } \\
\text { mięsa i produktów pochodzenia zwierzęcego w klubie }\end{array}$ \\
\hline Inicjowanie programów poza klubem & $\begin{array}{l}\text { Klub edukuje również poza stadionem. Prowadzi } \\
\text { liczne akcje w szkołach, oparte na programach } \\
\text { ambasadorskich }\end{array}$ \\
\hline Ekologiczne pamiątki dla kibiców & $\begin{array}{l}\text { Klubowy sklep zaopatrzony jest w ekologiczne } \\
\text { pamiątki }\end{array}$ \\
\hline Ekologiczne stroje & $\begin{array}{l}\text { Stroje wykonane są z ekologicznych materiałów. } \\
\text { Do ich produkcji wykorzystano m.in. fusy z kawy } \\
\text { i przetworzone tworzywa sztuczne. W trakcie mi- } \\
\text { nionych dwóch sezonów zawodnicy nosili koszulki } \\
\text { wykonane z bambusa }\end{array}$ \\
\hline
\end{tabular}

Źródło: Na podstawie oficjalnej strony klubu Forest Green Rovers (https://www.fgr.co.uk/).

Klub FGR działa dość kompleksowo. Podąża za misją, która została przedstawiona przez prezesa klubu na płaszczyźnie m.in. infrastruktury (panele fotowoltaiczne, stacje ładujące, banery informacyjne na stadionie); dba o edukację 
(programy edukacyjne dla piłkarzy, młodzieży, dzieci w szkołach) oraz dokonuje zmian wewnątrz przedsiębiorstwa, które bezpośrednio dotyczą pracowników (brak możliwości nabycia produktów zwierzęcych w klubowej restauracji, biodegradowalne kubki). Sama postawa prezesa klubu również świadczy o autentyczności całego projektu. Klub dba o środowisko na dwa sposoby - bezpośredni i pośredni. W sposób pośredni poprzez edukację, pokazywanie światu swojego fenomenu opartego na ekologicznych założeniach. Walczy również ze stereotypem, że osoby, które nie jedzą mięsa są słabsze fizycznie od osób spożywających produkty pochodzenia zwierzęcego (IV liga, w której gra klub, to przy stanie angielskiego futbolu nadal liga profesjonalna na wysokim poziomie, szczególnie fizycznym). Klub ma również bezpośredni wpływ na ochronę środowiska. Pokazują to raporty publikowane na stronie klubu. Łączny ślad emisyjny klubu spadł o 53\% w sezonie 2019/2020 w stosunku do sezonu 2018/2019 (FGR, n.d.). Na oficjalniej stronie klubu można znaleźć informację, że przy klubie funkcjonuje stowarzyszenie FGR, które działa w ramach fundacji Green Britain. Społeczność ta jest rodzajem wsparcia dla mieszkańców. Jej celem jest inspirowanie i motywowanie oraz edukowanie. Oprócz wspomnianej w tabeli 1 edukacji, stowarzyszenie zajmuje się dbaniem o lokalną integrację, zdrowie psychiczne, wspieranie osób chorych psychicznie i samotnych, a także walczy z biedą (FGR, 2021). W Polsce kluby nie podejmują prawie żadnych działań na rzecz ochrony środowiska, a jeśli już do tego dojdzie, to są one jednorazowe, nie stanowią elementu strategii (jak w przypadku klubu FGR).

\section{Dyskusja i wnioski}

Zdecydowana większość klubów, zarówno amatorskich, jak i profesjonalnych, w Polsce i za granicą, działa społecznie. Niewątpliwie dzieje się tak z różnych przyczyn. O ile można usłyszeć o wielu akcjach, które dotyczą działania na rzecz społeczności, o tyle widać zdecydowany brak działań na rzecz ochrony klimatu. Co prawda przykład FGR jest skrajny i w wielu miejscach mógłby spotkać się z bojkotem kibiców (np. ze względu na brak potraw mięsnych w punktach gastronomicznych, które uchodzą za nieodłączny element spotkań), lecz trzeba przyznać, że wspomniany wcześniej raport opracowany przez Sport Impact (Zembura et al., 2020) pokazuje, że nadal zbyt mało uwagi polskie kluby przykładają do promowania wartości, takich jak ochrona środowiska czy zrównoważony rozwój. Na świecie również nie jest to motyw przewodni akcji CSR. Co prawda istnieją kluby, jak np. Ajax Amsterdam, który na dachu swojego 
stadionu posiada 4200 paneli solarnych, jednak to nadal za mało, biorąc pod uwagę cały obszar piłki nożnej. MetLife Stadium w Nowym Jorku został zbudowany z 40 tys. ton przetopionego złomu, a wszystkie siedzenia wykonano z surowców wtórnych. Jednak aby odnaleźć taką informację, trzeba zapoznać się z materiałami branżowymi. W Polsce niewiele stadionów stosuje rozwiązania ekologiczne. Prawdopodobnie jedyny profesjonalny stadion, który zasilany jest panelami fotowoltaicznymi, to stadion Legionovii Legionowo. Niestety wynika to $\mathrm{z}$ faktu, że niewiele stadionów w Polsce należy do klubów. Są one zarządzane przez spółki miejskie. FGR jest przykładem, że można odnieść sukces marketingowy, społeczny (co za tym idzie zapewne finansowy), skupiając się na realizacji celów społecznych, a nie tylko sportowych - pokazują to publikacje na temat klubu, liczne wpisy na stronach internetowych oraz liczba ich fanów na portalach społecznościowych. Każdy kolejny wpis o klubie w mediach społecznościowych, ale również w monografiach naukowych, powoduje efekt kuli śnieżniej, który niesie przekaz - dbajmy o planetę, odżywiajmy się zdrowo, możesz być silny i sprawny, jak nasi piłkarze, i nie jeść mięsa.

Pod koniec XIX w., kiedy piłka nożna stała się dyscypliną masową, jej funkcje były silnie społeczne. Zrzeszała ludzi i dawała im rozrywkę. Z czasem stała się biznesem o niespotykanej skali, milionowych przychodach i rekordach transferowych. Jednak w tym czasie pojęcie społecznej odpowiedzialności biznesu wchodziło do nauki i praktyki. Przedsiębiorstwa, w tym przedsiębiorstwa sportowe, jakimi są kluby, zostały zobligowane do pomagania. Sama funkcja wychowania nowych zawodników może zostać zaliczona do działań CSR; szkółki działają w ramach fundacji, aby zapewnić szkolenie również dzieciom $\mathrm{z}$ ubogich rodzin. Akademia w ramach fundacji działa przy wielu klubach z I ligi oraz Ekstraklasy. Dodatkowo szkółki oraz kluby piłkarskie organizują dla młodzieży wiele szkoleń, które pomagają im nie tylko w karierze, ale również w życiu prywatnym. Są to bezpłatne warsztaty z dietetykami, psychologami i innymi specjalistami. Przykład klubu z Anglii pokazał, że można zbudować długofalową (trwającą już ponad 10 lat) strategię opartą na innowacyjnym pomyśle i dążyć do jej realizacji oraz czerpania z niej korzyści. Fakt, że klubem interesują się nawet polskie niesportowe media pokazuje, że cel, jakim był apel do społeczeństwa, został osiągnięty. Wiele organizacji podejmuje działania w ramach różnych inicjatyw. Mimo wszystko to klub z Anglii jest najczęściej opisywany przez dziennikarzy na całym świecie. Fakt, że klubem, który nie gra w pierwszej lidzie interesują się światowe media pokazuje, że innowacyjność jego działań jest wysoce atrakcyjna dla czytelników. Wraz z budową stabilnej 
drużyny i ewentualnym awansem do III, II, a może w przyszłości do I Ligi, klub będzie zdobywał coraz więcej fanów.

Przeprowadzona analiza wskazuje, że troszcząc się o środowisko, klub może odnieść realną korzyść, zarówno marketingową, jak i sportową czy wizerunkową. Świadczą o tym m.in. zasięgi, jakie generuje klub na swoich profilach społecznościowych (Facebook - ponad 50 tys. obserwujących, Instagram - 40 tys. obserwujących według stanu z dnia 2.05.2021 r.). Każdego rodzaju sport dysponuje cechami takimi jak kultura, zdrowie, rozwijanie pasji czy też ochrona środowiska naturalnego (Grabowski, 2020, s. 70-71). Jednak nawet jeśli kluby podejmują takie działania, to nie zawsze jest to odpowiednio nagłaśniane.

Działania klubu prowadzone są na dwóch płaszczyznach. Jedną z nich jest troska o środowisko (dążenie do neutralności węglowej, ograniczanie spożycia mięsa przez kibiców i zawodników), drugą - poprzez nagłośnienie swoich działań w skali globalnej - zachęcanie innych do zmian swoich nawyków. Zachodzą tutaj dwa procesy, które można rozpatrywać z perspektywy psychologicznej. Jednym z nich jest „efekt aureoli”, który polega na tym, że jeśli jedna cecha danej osoby lub organizacji jest oceniona pozytywnie, to mamy również skłonność przypisywać tej osobie, organizacji inne pozytywne cechy (Tyszka, 2010, s. 10). W przypadku klubów sportowych, jeśli działania np. FGR są odbierane przez ludzi pozytywnie, to również inne cechy klubu (lub procesy w nim zachodzące, np. skuteczność transferów) mogą być rozpatrywane pozytywnie przez kibiców, sponsorów czy pozostałych interesariuszy. Drugim efektem psychologicznym jest „efekt autorytetu”. W przypadku klubów, szczególnie regionalnych, kibicem w większości przypadków staje się podczas procesu socjalizacji. Kształtowanie kapitału kulturowego, gustów kulturowych w zakresie konsumpcji wydarzeń sportowych (również kibicowania) nabywa się często w procesie socjalizacji za sprawą osób znaczących, np. rodziców, rodzeństwa, nauczycieli (Lenartowicz, 2017, s. 67-69). Jednak sympatię do klubu można nabyć również w inny sposób - np. uznać go za autorytet. Za autorytet można uznać podmiot, który wyróżnia się z otoczenia na ogół rzadkimi cechami (Acewicz, 2012, s. 8-10). Jeśli dany kibic, np. FGR, do tej pory nie przykładał wagi do ograniczenia spożycia mięsa, a uznaje klub (lub danego jego piłkarza) za autorytet, to będzie skłonny zmienić swoje nawyki żywieniowe na rzecz działań klubu. Jeśli jednak jego zachowanie już jest nastawione na działanie proekologiczne i jest on fanem piłki nożnej, to poprzez wspólne cechy z innymi kibicami Zielonych Diabłów oraz klubem chętniej zostanie kibicem FGR. Kluby (i kibice) nie są wolne od ideologii i przekonań - przykładem byli kibice Lazio Rzym, którzy łączyli kibi- 
cowanie z ideologią faszystowską (Tartak, 2019). Osoby takie stają się kibicami nie ze względu na dobre wyniki sportowe, tylko aby znaleźć osoby o podobnych poglądach, przekonaniach i móc się z nimi identyfikować. Podobnie może być z „globalnymi” kibicami FGR, którzy przez sympatię do klubu chcą pokazać troskę o środowisko naturalne.

Szczególnie istotnym zwrotem dla niniejszego artykułu jest pojęcie kibica globalnego. Jest to kibic, który identyfikuje się z klubem znanym, mimo że nie pochodzi z kraju, gdzie klub gra. Jest to pewnego rodzaju przeciwwaga dla bycia kibicem lokalnym - czyli bycia kibicem drużyny z miasta/regionu, z którego się pochodzi. Wielu kibiców globalnych (co zostało wspominane we wstępie) ma np. Manchester United. Kibiców lokalnych mają głównie kluby, które nie osiągają sukcesów na arenie międzynarodowej, jak np. Legia Warszawa (Klimas \& Pietrzyk, 2018, s. 53). Wiele klubów podejmujących działania na rzecz społeczności skupia się głównie na społeczności lokalnej. Niemieckie kluby działają społecznie szczególnie na terenie regionu, gdzie występują (Grabowski, 2017, s. 129). To samo dotyczy polskich klubów piłkarskich, które najchętniej wspierają inicjatywy regionalne - jak np. Legia Warszawa. Pozwala to na zyskanie nowych kibiców lokalnych lub wykorzystanie wcześniej wspomnianego efektu aureoli. W przypadku opisywanego klubu z Anglii działania na rzecz ochrony klimatu mają wymiar globalny, co pozwala na zyskanie sympatii i rozgłosu globalnego, a także na rozszerzenie grona kibiców globalnych, zwanych inaczej flaneur (franc. włóczęga), czyli kibicami utożsamiającymi się z klubem, który może być oddalony od nich o setki kilometrów i znają go tylko z przekazu medialnego. Są to grupy kibiców, np. Manchester United, rozsiane po całym świecie (Giulianotti, 2002). W przeciwieństwie do poprzednich grup nie nabyli oni miłości do klubu w procesie socjalizacji. W innej klasyfikacji kibiców klubów piłkarskich, zaproponowanej przez Sue Bridgewater, kibice, którzy utożsamiają się z klubem, mimo braku związku z regionem, który klub reprezentuje, to e-kibice (Bridgewater, 2010, s. 69-70). Grupa kibiców globalnych - flaneur czy e-kibiców - również wpływa na przychód klubów sportowych w istotny sposób, zarówno bezpośredni, np. kupując rzeczy w sklepie internetowym klubu, jak i pośredni - tworząc ruch na stronie internetowej czy mediach społecznościowych. Dlaczego jest to istotne z punktu widzenia omawianego klubu FGR? Kluby o długiej historii (dla przykładu Manchester United, Chelsea, Bayern) mogą liczyć na wsparcie kibiców z innych państw, jednak stoją za tym coroczne wyniki w rozgrywkach międzynarodowych. Klub FGR nie odniósł sukcesów na polu międzynarodowym i gra w lidze, która nie jest obiektem zainteresowań kibiców 
na całym świecie (w przeciwieństwie do Premier League, Championship, Ligi Mistrzów, Ligi Europy, Serie A, La Ligi). Jednak dzięki specyfice swoich działań oraz niszowym akcjom, znajduje on zwolenników na całym świecie, którzy kierują się w życiu podobnymi wartościami. Dzięki temu klub zyskuje popularność poza swoim regionem (co w przypadku klubów, które nigdy nie odniosły sukcesu sportowego na szczeblu centralnym jest niebywale trudne), a ponadto edukuje innych. Jest to szczególnie istotne, gdyż działania proekologiczne są bezpośrednio wpisane w całą strategię klubu i w odróżnieniu od pojedynczych działań innych klubów mają wymiar ciągły. Polepszające się wyniki sportowe (w dniu 4.05.2021 r. klub znajduje się w strefie barażowej, która umożliwia historyczny awans do League One - trzeci poziom rozgrywkowy w Anglii) pokazują, że obok sukcesu marketingowego i społecznego można również zaobserwować sukces sportowy, który jest celem nadrzędnym przedsiębiorstw sportowych.

Nieodłącznym elementem zarządzania przedsiębiorstwem jest budowa jego strategii. Przedsiębiorstwo na rynku wyróżnia również wizja, misja oraz cel. Podany przykład klubu FGR idealnie pokazuje, że wizja oraz misja przedsiębiorstwa i dobrze przemyślana, konsekwentnie realizowana strategia, mogą prowadzić do sukcesu na wielu płaszczyznach. Klub niewątpliwie odniósł olbrzymi sukces społeczny, rozumiany jako sukces klubu na rzecz społeczeństwa (w tym przypadku nie tylko lokalnego). Sama liczba publikacji, wzmianek o klubie w kontekście jego działań na rzecz środowiska naturalnego powoduje, że można również stwierdzić, że klub odniósł sukces na płaszczyźnie marketingowej, gdyż jest rozpoznawalny nie tylko przez ekspertów brytyjskiego futbolu, ale również przez osoby, które na co dzień nie są związane z piłką nożną. Klub odnosi także sukces sportowy i stoi przed szansą awansu na trzeci poziom rozgrywek (co jest wysokim wynikiem, biorąc pod uwagę ogólny poziom piłki nożnej w Anglii oraz fakt, że w samym pucharze Anglii udział biorą drużyny do XI poziomu rozgrywkowego, a w niektórych regionach szczeble ligowe kończą się na XXIV lidze). Sama wartość zawodników grających w składzie FGR szacowana jest według portalu Transfermarkt.de na 1,65 mln EUR (Transfermarkt, n.d.). Stanowi to kolejny dowód na to, że jest to w pełni profesjonalny klub piłkarski, który dba o swoje sukcesy na różnych płaszczyznach: marketingowej, społecznej, sportowej i finansowej (o czym świadczy wartość składu, mimo braku spektakularnych transferów).

Rekomendacją zarządczą dla klubów w Polsce jest znalezienie niszy w popularnym obszarze, jakim jest ekologia, i próba realizacji części działań prospołecznych w segmencie proekologicznym. Jeśli kluby w Polsce nie mogą stać się 
markami o zasięgu europejskim, gdyż nie realizują celów sportowych, to może próba zdobycia rozgłosu poprzez działania na rzecz zrównoważonego rozwoju przyczyni się do wzrostu rozpoznawalności klubów z Polski na arenie międzynarodowej.

Adrian Pietrzyk - Szkoła Doktorska - nauki o zarządzaniu i jakości. Od 2017 r. Prezes Koła Naukowego „Ekonomia Sportu” na Uniwersytecie Ekonomicznym w Katowicach

\section{Spis literatury}

Acewicz, M. (2012). Czynniki wiążące autorytetu. Ekonomia i Zarządzanie, 4(3), 7-23.

Bankier. (2019). Te sporty sa w Polsce najpopularniejsze. Pobrano z: https://www.bankier. $\mathrm{pl} /$ wiadomosc/Najpopularniejsze-sporty-w-Polsce-Najchetniej-trenowana-pilka-no zna-7715481.html (dostęp: 1.08.2021).

Beardmore, A., Jones, M., \& Biddle, M. (2020). Strengthening Local Communities programme evaluation: Forest Green project. UWE Bristol: Gloucestershire Clinical Commissioning Group and Gloucestershire County Council.

Bernatt, M. (2009). Społeczna odpowiedzialność biznesu. Wymiar konstytucyjny i międzynarodowy. Warszawa: Wydawnictwo Naukowe Wydziału Zarządzania Uniwersytetu Warszawskiego.

Bridgewater, S. (2010). What is a football brand? In Football Brands. London: Palgrave Macmillan, https://doi.org/10.1057/9780230281363

Ceglińska, M. (2015). Selected aspects of environmental management on the example of British football clubs. Quality in Sport, 1(4). https://doi.org/10.12775/QS.2015.019

Climate Action. (2017). World's most sustainable football club wins league promotion. Pobrano z: https://www.climateaction.org/news/worlds-most-sustainable-footballclub-wins-league-promotion (dostęp: 1.08.2021).

Czakon, W., Klimas, P., \& Kawa, A. (2019). Krótkowzroczność strategiczna: metodyczne aspekty systematycznego przeglądu literatury. Studia Oeconomica Posnaniensia, 7(2), 27-37. https://doi.org/ 10.18559/SOEP.2019.2.2

Deloitte. (2020). Raport: Football Money League 2020.

Dziennik Trybuna. (n.d.). Klub wegański oraz ekologiczny. Pobrano z: https://trybuna. info/sport/klub-weganski-oraz-ekologiczny (dostęp: 1.08.2021).

Generalna Dyrekcja Ochrony Środowiska. (n.d.). System ekozarzadzania i audytu EMAS. http://emas.gdos.gov.pl/files/aktualnosci/174139/Folder-EMAS_publikacja_news_ image.pdf (dostęp: 1.08.2021).

FlashScore.com. (n.d.). Forest Green. Pobrano z: https://www.flashscore.com/team/forestgreen/v7ZNnsJG/ (dostęp: 1.08.2021). 
Forbes. (2018). Lista „Forbes” 100 najlepiej zarabiajacych celebrytów na świecie. Pobrano z: https://www.forbes.pl/life/100-najlepiej-zarabiajacych-celebrytow-naswiecie-2018/698s2qf (dostęp: 1.08.2021).

Forest Green Rovers. (2021). FGR community, Pobrano z: https://www.fgr.co.uk/fgrcommunity (dostęp: 1.08.2021).

Forest Green Rovers. (n.d.). Our ethos. Greeneng up football. Pobrano z: https://www.fgr. co.uk/our-ethos/greening-up-football (dostęp: 14.03.2021).

Giulianotti, R. (2002). Supporters, followers, fans, and flaneurs: A taxonomy of spectator identities in football. Journal of Sport and Social Issues, 26(1), 30-41. http:// doi.org/10.1177/0193723502261003

Grabowski, A. (2017). Działalność niemieckich przedsiębiorstw sportowych (piłkarskich) a społeczna odpowiedzialność biznesu. Annales. Etyka w Życiu Gospodarczym, 20(3), s. 121-130. http://doi.org/:10.18778/1899-2226.20.3.09

Grabowski A., (2020). Polskie profesjonalne kluby piłkarskie wobec CSR. W: G. Botwina (red.). Zarzadzanie w polskim sporcie (s. 69-82). Warszawa: Polskie Wydawnictwo Ekonomiczne.

James, S. (2017). Forest Green: The eco-friendly club with a robot mower and big ambitions. Pobrano z: https://www.theguardian.com/football/2017/jul/31/forest-greenrovers-league-two (dostęp: 1.08.2021).

Kantor, A., \& Kubiczek, J. (2021). Polish culture in the face of the COVID-19 pandemic crisis. Journal of Risk and Financial Management, 14(4), 181. https:// doi.org/10.3390/jrfm14040181

Klimas, P., \& Pietrzyk, A. (2018). Wykorzystanie koncepcji BMC na przykładzie klubów pitkarskich. Fundacja Biznesu i Nauki, 53-102.

Klimas, P. (2011). Bliskość organizacyjna - krytyczny przegląd literatury źródłem inspiracji badawczej. W: I. Pyka (red.), Nowoczesność przemysłu i ustug. Dynamika zmian w polskim przemyśle i ustugach (s. 169-184). Katowice: TNOiK.

Kubiak, I. (2018). Ponad połowa populacji świata ogladała mundial. FIFA chwali się rekordem. Pobrano z: https://sportowefakty.wp.pl/pilka-nozna/795382/ponad-polowapopulacji-swiata-ogladala-mundial-fifa-chwali-sie-rekordem (dostęp: 1.08.2021).

Kubiczek, J. (2019). Wyzwania instytucji kultury w zakresie marketingu i sponsoringu przez biznes. W: B. Reformat, A. Kwiecień, \& A. Nocoń A. (red.), Biznes w kulturze - kultura $w$ biznesie. Nowe trendy $w$ otoczeniu jednostek kultury (s. 41-50). Katowice: Wydawnictwo Uniwersytetu Ekonomicznego.

Kubiczek, J. (2020). Etyka i społeczna odpowiedzialność biznesu na przykładzie linii lotniczych. Marketing i Rynek, 10, s. 23-29. https://doi.org/10.33226/1231-7853. 2020.10.3

Kuraszko, I., \& Rok, B. (2007). Społeczna odpowiedzialność biznesu i ekonomia społeczna. Ekonomia Społeczna. Teksty. Pobrano z: www.1ublin.ngo.pl/files/ekonomia spoleczna.pl/public/teksty2007/080304_ES_teskty_2007_Kuraszko_Rok.pdf (dostęp: 1.08.2021). 
Lenartowicz, M. (2017). Socjalizacja konsumentów sportu. Rozprawy Naukowe Akademii Wychowania Fizycznego we Wrocławiu, 57, 62-72.

Liverpool FC. (n.d.). Official LFC supporters clubs. Pobrano z: https://www.liverpoolfc. com/fans/official-lfc-supporters-clubs (dostęp: 1.08.2021).

Mizerek, H. (2017). Studium przypadku w badaniach nad edukacją. Istota i paleta zastosowań. Przeglad Pedagogiczny, 1, 9-22.

Manchester United FC. (n.d.). Manchester United supporters' clubs. Pobrano z: https:// www.manutd.com/en/fans/supporters-clubs (dostęp: 1.08.2021).

Meczyki. (n.d.). Liczba klubów piłkarskich wg województw. Pobrano z: https://www. meczyki.pl/sportbuzz/liczbaklubowpilkarskichwgwojewodztw/147961 (dostęp: 1.08. 2021).

Onet. (2016). Polska - Portugalia: padt rekord oglądalności. Pobrano z: https://sport. onet.pl/pilka-nozna/euro-2016/euro-2016-polska-portugalia-padl-rekord-ogladalnosci/ e59dkd (dostęp: 1.08.2021).

Orłowska, A., Mazur, Z., \& Łaguna, M. (2017). Systematyczny przegląd literatury: Na czym polega i czym różni się od innych przeglądów? Ogrody Nauk i Sztuk, 7, 350-363.

PKN. (2013). ISO 26000. Guidance on social responsibility. Norma Międzynarodowa dotyczaca społecznej odpowiedzialności. Pobrano z: https://www.pkn.pl/informacje/ 2013/09/iso-26000 (dostęp: 1.08.2021).

PolskieRadio24.pl. (2016). Ekologiczny stadion, wegańskie menu i „zielony” wtaściciel to najbardziej alternatywny klub świata? Pobrano z: https://polskieradio24.pl/43/265/ Artykul/1696773,Ekologiczny-stadion-weganskie-menu-i-zielony-wlasciciel-to-naj bardziej-alternatywny-klub-swiata (dostęp: 1.08.2021).

Raport Deloitte (2020), Football Money League 2020, Pobrano z: https://www2.deloitte. $\mathrm{com} / \mathrm{pl} / \mathrm{pl} /$ pages/consumer-business/articles/deloitte-football-money-league-2020.html (dostęp: 1.08.2021).

SportsShow. (2021).Top 10 most popular sports in the world. 2021 power ranking. Pobrano z: https://sportsshow.net/top-10-most-popular-sports-in-the-world (dostęp: 1.08.2021).

Samuel, A. (2018). Macromarketing insights ninety minutes at a time: A season with Forest Green Rovers, the world's greenest football club. Presented at: Macromarketing Conference, Leipzig, 9-12 July 2018. Proceedings Macromarketing Conference 2018. Macromarketing Society Inc.

Skałecka, K. (2017). Społeczna odpowiedzialność biznesu w sporcie. Analiza przykładowych działań krajowych i zagranicznych organizacji sportowych. Przeglad Współczesnych Problemów Zarządzania, 3, 20-31.

Stake, R.E. (1997). Studium przypadku. W: L. Korporowicz (red.), Ewaluacja w edukacji. Warszawa: Oficyna Naukowa. 
Sznajder, M. (2013). Korzyści z wdrożenia koncepcji społecznej odpowiedzialności biznesu (z uwzględnieniem koncepcji interesariuszy). Ekonomia i Zarządzanie, 5(2), 194-211. https://doi.org./10.12846/j.em.2013.02.12

Tartak, J. (2019). The problem of racism in European football. Kultura Bezpieczeństwa. Nauka - Praktyka - Refleksje, 34(34), 155-181. https://doi.org/10.5604/01.3001. 0013.5191

Transfermarkt. (n.d.). Pobrano z: https://www.transfermarkt.pl/forest-green-rovers/rekord abgaenge/verein/3455 (dostęp: 1.08.2021).

Tyszka, T. (2010). Pułapki oceniania. Decyzje, 13, 5-25.

World Atlas. (2020). The most popular sports in the world. Pobrano z: https://www. worldatlas.com/articles/what-are-the-most-popular-sports-in-the-world.html (dostęp: 1.08.2021).

Zembura, P. et al. (2020). Analiza odpowiedzialności społecznej klubów Fortuny 1 Ligi $w$ sezonie 2019/2020. Warszawa: Fundacja Institute for Sport Governance. Pobrano z http://govsport.eu (dostęp: 1.08.2021).

Zuzek, D. K. (2012). Społeczna odpowiedzialność biznesu a zrównoważony rozwój przedsiębiorstw. Zeszyty Naukowe Małopolskiej Wyższej Szkoły Ekonomicznej w Tarnowie, 21(2), 197-207. https://doi.org/10.25944/znmwse.2012.02.197207

\title{
Actions of football clubs in favour of environment protection - Forest Green Rovers case study
}

\begin{abstract}
The article focuses on the essence of pro-social activities in the area of environmental care. The first part of the article presents the essence and outline of CSR activities. In the methodological part, the diagnosis was made using a case study. The subject of the research was the English club Forest Green Rovers, which is considered to be the most ecological club in the world. The exploratory cognitive goal at work is to identify the differences between clubs in Poland and the English club Forest Green Rovers. The utilitarian goal is to spread awareness of the social role that the club should fulfill. Both its current activities aimed at increasing interest in topics in the field of ecology, as well as plans for the future were presented. The last part of the article also includes management implications for Polish football clubs.
\end{abstract}

Keywords: sports management, sports marketing, CSR.

JEL Classification: Z20. 